Available online at Dakwah: Jurnal Kajian Dakwah dan Kemasyarakatan
http://journal.uinjkt.ac.id/index.php/dakwah
Dakwah: Jurnal Kajian Dakwah dan Kemasyarakatan, 24 (1), 2020, 13-33

\title{
Prinsip-Prinsip Komunikasi dan Informasi dalam Perspektif Al-Qur'an Membangun Komunikasi Beradab
}

\author{
A. Husnul Hakim \\ husnul_imzi@ptiq.ac.id
}

Fakultas Ushuluddin dan Direktur Lembaga Pengkajian

Al-Qur'an dan Tafsir [eLKAF] Institut PTIQ

\begin{abstract}
Communication is not only informative but also persuasive. Moreover, the mass communcation which could be effective in forming public opinion. Therefore, it is necessary to apply the principles of communication that are mutually agreed consistently and responsibly. Because the error especially the mass communication will cause a great impact on society. There is a need for correction about the cognitive understanding of the public on terms that are known especially in the world of journalism, such as check and recheck, fairness, accuracy, free and responsible, and others. Do not let these principles actually gave birth to a new arrogance in communicating. This article tries to correct the understanding of the society based on the Qur'an and as-Sunnah.
\end{abstract}

Keyword: Mass communication, persona communication, informative

\begin{abstract}
Abstrak
Komunikasi tidak hanya bersifat informatif tetapi juga persuasif. Apalagi komunikasi massa yang dapat efektif membentuk opini publik. Oleh karena itu, prinsip komunikasi yang disepakati bersama harus diterapkan secara konsisten dan bertanggung jawab. Karena kesalahan khususnya dalam komunikasi massa akan menimbulkan dampak yang besar di masyarakat. Perlu ada koreksi terkait pemahaman kognitif masyarakat terhadap istilah-istilah yang dikenal khususnya dalam dunia jurnalistik, seperti check and recheck, fairness, akurasi, bebas dan bertanggung jawab, dan lain-lain. Jangan sampai prinsip tersebut justru melahirkan keangkuhan baru dalam berkomunikasi. Artikel ini mencoba meluruskan pemahaman masyarakat berdasarkan Al-Qur'an dan As-Sunnah.

Kata Kunci: Komunikasi massa, komunikasi persona, informatif
\end{abstract}

Permalink/DOI: http://doi.org/10.15408/dakwahv24i1.17808

\section{Pendahuluan}

Kemampuan berbicara bagi manusia adalah anugerah yang sangat besar. Kemampuan bicara membuat manusia dapat mengungkapkan pengalaman dan kenangan dan mengutarakan maksud. Hubungan sosial pun ia bangun dengan kemampuan bicara. Hal ini diisyaratkan oleh Al-Qur'an: (Dia) mengajarnya pandai berbicara (al-bayān). (arRaḥmân/55: 4). 
Istilah al-bayān dapat ditafsirkan dengan banyak arti, namun arti yang kuat adalah berbicara (an-nutq, alkalâm). ${ }^{1}$ Bahkan Ibn 'Asyur mengatakan, kata al-bayân juga mencakup isyarahisyarah lainnya, seperti kerlingan mata, anggukan kepala, dan lain-lain. Ia berargumentasi, meskipun isyarahisyarah itu tidak termasuk kategori annuț, namun ia termasuk ciri-ciri manusia. Jadi salah satu karunia terbesar bagi manusia adalah albayān. Ia bukan saja menjadi jati diri manusia, namun yang terpenting adalah ia menjadi pembeda dari binatang. ${ }^{2}$ Anjing boleh jadi bisa menggonggong, namun ia tidak bisa berbicara untuk menceritakan masa lalunya, mengungkapkan isi hatinya, dan sebagainya. Kemampuan bicara juga sebagian tidak bisa digantikan tulisan.

Namun begitu, masyarakat umum seringkali mengidentikkan berkomunkasi dengan berbicara. Atau dengan kata lain, ketika seseorang sedang berbicara dengan orang lain, biasanya ia dikatakan sedang berkomunikasi. Apakah pembicaraan itu ada manfaatnya atau sekedar obrolan warung kopi; apakah dilakukan berdua atau orang banyak; apakah bersifat rahasia atau umum, itu tidak penting. Sebab yang penting bahwa masingmasing yang hadir di tempat itu saling berbicara, beradu argumentasi, atau ngobrol ngalor-ngidul.

\section{A. Penjelasan Umum Komunikasi}

Istilah komunikasi, pada mulanya berasal dari bahasa latin communicatio, dan seakar kata dengan communis yang berarti sama, yang dimaksud adalah sama makna. Dalam artian, mengerti bahasanya belum tentu mengerti makna yang dibawa bahasa itu. Di sini menjadi jelas, sebuah pembicaraan dikatakan komunikatif jika keduanya, selain mengerti bahasa yang digunakan, juga mengerti makna dari bahan yang dibicarakan. ${ }^{3}$

Menurut para pakar komunikasi , pesan komunikasi bukan hanya menyangkut informasi tetapi juga persuasi. Tak sedikit informasi yang tampak seperti informasi atau cerita biasa padahal mengandung pesan atau bahkan iklan. Dengan begitu komunikasi memiliki kemampuan untuk membentuk bahkan menggiring pendapat umum (public opinion) dan sikap publik (public attitude). 4

Dari segi prosesnya, komunikasi bisa menggunakan berbagai media, seperti bahasa, isyarat, gambar, warna, atau apa saja yang secara langsung bisa "menerjemahkan" pikiran atau perasaan komunikator kepada komunikan. Namun dari banyak media tersebut, bahasalah yang paling menonjol dan sering digunakan. Sebab, bahasa merupakan media komunikasi yang paling umum, di mana hampir setiap orang mampu berbahasa untuk mengutarakan pikiran dan juga mengerti pikiran orang lain. 5 Bahasa juga bisa menunjukkan kualitas seeorang, apakah ia terpelajar atau tidak. Sebuah ungkapan Arab mengatakan:

الكلام صفة المتكلم "Ucapan atau perkataan menggambarkan kualitas si pembicara'. ${ }^{6}$ Sementara yang dimaksud dengan komunikasi secara sekunder 
adalah proses penyampaian pesan oleh seseorang kepada orang lain dengan menggunakan alat atau sarana sebagai media kedua setelah memakai lambang sebagai media pertama. 7 Misalnya melalui surat kabar, telepon, radio, televisi, internet, dan lain sebagainya. Namun, mayoritas para ahli komunikasi menyatakan media yang paling efektif dan efisien dalam menyampaikan pesanpesan persuasif adalah komunikasi tatap muka; di mana si komunikator dapat mengetahui langsung respons atau reaksi dari komunikan. ${ }^{8}$

Secara umum, komunikasi bisa dibedakan dalam dua hal, yaitu komunikasi antarpersona (interpersonal communication) dan komunikasi massa (mass communication). Komunikasi antarpersona adalah komunikasi yang dilakukan secara dua arah (two-way traffic communication); sedangkan komunikasi massa adalah komunikasi yang berlangsung satu arah (one-way communication). 9

\section{Etika Berkomunikasi menurut al- Qur'an}

Berkomunikasi adalah sesuatu yang dihajatkan di hampir setiap kegiatan manusia. Dalam sebuah penelitian telah dibuktikan, hampir $75 \%$ sejak bangun dari tidur manusia berada dalam kegiatan komunikasi. Dengan komunikasi, seseorang dapat membentuk saling pengertian dan menumbuhkan persahabatan, memelihara kasih sayang, menyebarkan pengetahuan, dan melestarikan peradaban. Namun, dengan komunikasi, juga dapat menumbuhsuburkan perpecahan,

menghidupkan permusuhan, menanamkan kebencian, merintangi kemajuan, dan menghambat pemikiran. ${ }^{10}$

Kenyataan ini sekaligus memberi gambaran betapa kegiatan komunikasi bukanlah sesuatu yang mudah dilakukan oleh setiap manusia. Anggapan ini barangkali didasarkan atas sebuah assumsi bahwa komunikasi merupakan suatu yang lumrah dan alamiah yang tidak perlu dipermasalahkan. Sedemikian lumrahnya, sehingga seseorang cenderung tidak melihat kompleksitasnya atau tidak menyadari bahwa dirinya sebenarnya berkekurangan atau tidak berkompeten dalam kegiatan pribadi yang paling pokok ini. Dengan demikian, berkomunikasi secara efektif sebenarnya merupakan suatu perbuatan yang paling sukar dan kompleks yang pernah dilakukan seseorang. ${ }^{11}$

Berangkat dari pandangan tersebut, perlu diformulasikan etika berkomunikasi, baik antarpersona maupun komunikasi massa, yang bersumber dari al-Qur'an maupun hadis

\section{Etika dalam Komunikasi Antarpersona}

Berdasar pada penjelasan di atas, dimana komunikasi antarpersona berlangsung secara dua arah, maka penggunaan bahasa yang tepat menjadi kebutuhan yang paling asasi dalam rangka bermetakomunikasi (membangun hubungan sosial). Di dalam Al-Qur'an banyak ditemukan term-term yang bisa dianalisa sebagai dukungan dari terciptanya komunikasi 
antarpersona yang baik, santun, dan beradab tersebut, yaitu:

\section{a. Qaul Balîg}

Term qaul balìg dalam Al-Qur'an hanya disebutkan sekali, yaitu surah anNisa'/4: 63:

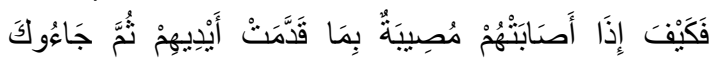

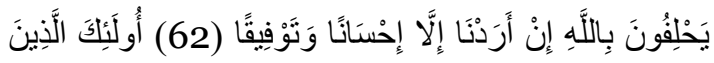



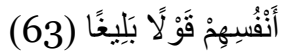

Maka bagaimana halnya apabila (kelak) musibah menimpa mereka (orang munafik) disebabkan perbuatan tangannya sendiri, kemudian mereka dating kepadamu (Muhammad) sambil bersumpah, "Demi Allah, kami sekalikali tidak menghendaki selain kebaikan dan kedamaian." Mereka itu adalah orang-orang yang (sesungguhnya) Allah mengetahui apa yang ada di dalam hatinya. Karena itu berpalinglah kamu dari mereka, dan berilah mereka nasihat, dan katakanlah kepada mereka perkataan yang membekas pada jiwanya. (an-Nisā'/4: 62-63)

Ayat ini menginformasikan tentang kebusukan hati kaum munafik, bahwa mereka tidak akan pernah bertahkim (memohon fatwa hukum) kepada Rasulullah saw., meski mereka telah bersumpah atas nama Allah, kalau apa yang mereka lakukan itu sematamata menghendaki kebaikan. Walaupun begitu, beliau tetap dilarang menghukumi mereka secara fisik (makna dari "berpalinglah dari mereka"), akan tetapi, cukup memberi nasehat sekaligus ancaman bahwa perbuatan buruknya akan mengakibatkan turunnya siksa
Allah. ${ }^{12}$ Dalam hal ini, beliau dituntut agar mampu mengkomunikasikannya dengan qaul balîg.

Term balîg, yang berasal dari $b a$ la ga, dipahami sebagai sampainya sesuatu kepada sesuatu yang lain. Juga bisa dimaknai dengan "cukup" (alkifāyah). Karena itu, perkataan yang balìg adalah setiap perkataan yang merasuk dan membekas ke dalam jiwa. ${ }^{13}$ Menurut al-Ișfahânî, perkataan yang balîg mengandung tiga unsur, yaitu bahasanya tepat, sesuai dengan yang dikehendaki, dan isi perkataan adalah suatu kebenaran. Term balīg juga berarti bahwa si pembicara secara sengaja hendak menyampaikan sesuatu dengan cara yang benar agar bisa diterima oleh pihak yang diajak bicara. ${ }^{14}$

Secara lebih terperinci, para pakar sastra, seperti yang dikutip oleh Quraisy Shihab, membuat kriteriakriteria khusus yang memungkinkan suatu pesan dianggap balīg, antara lain:15 Tertampungnya seluruh pesan dalam kalimat yang disampaikan; kalimatnya tidak bertele-tele, namun juga tidak terlalu pendek sehingga pengertiannya menjadi kabur; pilihan kosa katanya tidak dirasakan asing bagi si pendengar, dan mudah diucapkan; kesesuaian kandungan dan gaya bahasa dengan lawan bicara; kesesuaian dengan tata bahasa.

\section{b. Qaul Karīm}

Term ini ditemukan di dalam alQur'an hanya sekali, yaitu surah alIsra'/17: 23: 


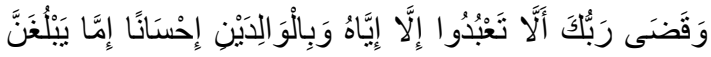

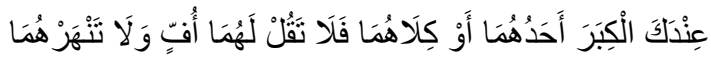

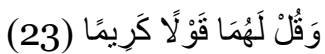
Dan Tuhanmu telah memerintahkan agar kamu jangan menyembah selain Dia dan hendaklah berbuat baik kepada ibu bapak. Jika salah seorang di antara keduanya atau kedua-duanya sampai berusia lanjut dalam pemeliharaanmu, maka sekalikali janganlah engkau mengatakan kepada keduanya perkataan "ah" dan janganlah engkau membentak keduanya, dan ucapkanlah kepada keduanya perkataan yang baik. (Q.s. alIsra'/17: 23)

Ayat di atas menginformasikan, ada dua ketetapan Allah yang menjadi kewajiban setiap manusia, yaitu menyembah Allah dan berbakti kepada kedua orang tua. Ajaran ini sebenarnya ajaran kemanusiaan yang bersifat umum, karena setiap manusia pasti menyandang dua predikat, yaitu sebagai makhluk ciptaan Allah dan anak dari kedua orang tuanya. Bukan hanya itu, struktur ayat ini, dimana dua pernyataan tersebut dirangkai dengan huruf wawu 'athaf, yang salah satu fungsinya adalah menggabungkan dua pernyataan yang tidak bisa saling dipisahkan (li mutlaq aljam'), ${ }^{16}$ menunjukkan bahwa berbakti kepada kedua orag tua menjadi parameter bagi kualitas penghambaan manusia kepada Allah.

Berkaitan dengan inilah, alQur'an memberikan petunjuk bagaimana cara berprilaku dan berkomunikasi secara baik dan benar kepada kedua orang tua, terutama sekali, di saat keduanya atau salah satunya sudah berusia lanjut. Dalam hal ini, al-Qur'an menggunakan term karim, yang secara kebahasaan berarti mulia. Term ini bisa disandarkan kepada Allah, misalnya, Allah Maha Karim, artinya Allah Maha Pemurah; juga bisa disandarkan kepada manusia, yaitu menyangkut keluhuran akhlak dan kebaikan prilakunya. Artinya, seseorang akan dikatakan karim, jika kedua hal itu benar-benar terbukti dan terlihat dalam kesehariannya. ${ }^{17}$

Namun, jika term karim dirangkai dengan kata qaul atau perkataan, maka berarti suatu perkataan yang menjadikan pihak lain tetap dalam kemuliaan, atau perkataan yang membawa manfaat bagi pihak lain tanpa bermaksud merendahkan. ${ }^{18}$ Dalam kaitan ini, Sayyid Quthb menyatakan bahwa dalam konteks hubungan dengan kedua orangtua, perkataan yang karim adalah tingkatan yang tertinggi yang harus dilakukan oleh seorang anak. Yakni, bagaimana ia berkata kepadanya, namun keduanya tetap merasa dimuliakan dan dihormati.19

Ibn 'Asyur juga menyatakan bahwa qaul karim adalah perkataan yang tidak memojokkan pihak lain yang membuat dirinya merasa seakan terhina. Contoh yang paling jelas adalah ketika seorang anak ingin menasehati orang tuanya yang salah, yakni dengan tetap menjaga sopan santun dan tidak bermaksud menggurui, apalagi sampai menyinggung perasaannya. ${ }^{20}$ Yang pasti qaul karim, adalah setiap perkataan yang dikenal lembut, baik, yang mengandung unsur pemuliaan dan penghormatan. Bahkan, Imam 'Ațâ' menambahkan bahwa ucapan tersebut 
tidak disertai dengan suara yang tinggi dan mata yang melotot. ${ }^{21}$

\section{c. Qaul Maisūr}

Di dalam al-Qur'an hanya ditemukan sekali saja, yaitu surah al-Isra'/17: 28:

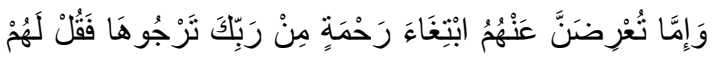

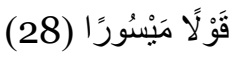

Dan jika engkau berpaling dari mereka untuk memperoleh rahmat dari Tuhanmu yang engkau harapkan, maka katakanlah kepada mereka ucapan yang lemah lembut. (Q.s. al-Isra'/17: 28)

Ayat ini turun berkenaan dengan sikap penolakan beliau untuk mengabulkan permintaan salah seorang sahabatnya, disebabkan ketidakamanahannya dalam menggunakan harta, karena menggunakan hartanya untuk hal-hal yang tidak ada manfaatnya. Sikap beliau ini justru diapresiasi sebagai sesuatu yang terpuji. Sebab, dengan begitu beliau tidak mendukung kebiasaan buruk tersebut. Di sisi lain, sikap tersebut juga dianggap bisa mendatangkan rahmat Allah." Namun begitu, beliau tetap dituntut untuk menyampaikannya dengan perkataan yang lembut, yang melegakan hatinya atau tidak menyinggung perasaannya. ${ }^{22}$

Ayat ini juga mengajarkan, kalaulah tidak bisa memberi karena memang tidak ada, namun tetap disertai dengan perkataan yang baik dan alasan-alasan yang rasional. Pada prinsipnya, qaul maisūr adalah segala bentuk perkataan yang baik, lembut, dan melegakan. ${ }^{23}$ Ada juga yang menjelaskan, qaul maisūr adalah menjawab dengan cara yang sangat baik, perkataan yang lembut dan tidak mengada-ada. Ada juga yang mengidentikkan qaul maisūr dengan qaul ma'rūf. Artinya, perkataan yang maisūr adalah ucapan yang wajar dan sudah dikenal sebagai perkataan yang baik bagi masyarakat setempat. ${ }^{24}$

\section{d. Qaul Ma'rū f}

Di dalam al-Qur'an term ini disebutkan sebanyak empat kali, yaitu surah al-Baqarah/2: 235, al-Nisā'/4: 5 dan 8, al-Ahzāb/33: 32. Di dalam surah al-Baqarah/2: 235, qaul ma 'rūf disebutkan dalam konteks meminang wanita yang telah ditinggal mati suaminya. Sementara di dalam surah anNisa'/4: 5 dan 8, qaul ma 'rūf dinyatakan dalam konteks tanggung jawab atas harta seorang anak yang belum mampu memanfaatkannya secara benar (safih). Sedangkan di Q.s. al-Ahzab/33: 32, qaul ma 'rūf disebutkan dalam konteks istriistri Nabi Saw.

Menurut Ibn 'Asyūr, qaul ma 'rūf adalah perkataan baik yang melegakan dan menyenangkan lawan bicaranya. ${ }^{25}$ Sementara al-Isfahānī menyatakan, term ma `rūf menyangkut segala bentuk perbuatan yang dinilai baik oleh akal dan syara'. ${ }^{26}$ Dari sinilah kemudian muncul pengertian bahwa ma 'rūf adalah kebaikan yang bersifat lokal. Sebab, jika akal dijadikan sebagai dasar pertimbangan dari setiap kebaikan yang muncul, maka tidak akan sama dari masing-masing daerah dan lokasi.

Kata $m a$ `ru $f$ disebutkan di dalam al-Qur'an sebanyak 38 kali, yang disebutkan dalam beberapa konteks, antara lain, tebusan dalam masalah pembunuhan setelah mendapatkan 
pemaafan, wasiyat, talak, nafkah, mahar, 'iddah, pergaulan suami-istri, berdakwah, pengelolaan harta anak yatim, pembicaraan atau ucapan, dan dengan ketaatan kepada Allah dan RasulNya. Yang jelas, term-term ma ‘rūf yang disebutkan dalam beberapa konteks di atas, seluruhnya berarti kebaikan yang sudah dikenal oleh mereka yang tinggal di tempat tersebut.

Ayat di atas mencontohkan pembagian warisan, yang di sana hadir beberapa kerabat yang ternyata tidak memperoleh bagian warisan tersebut, juga orang-orang miskin dan anak-anak yatim. Dalam hal ini, al-Qur'an memerintahkan agar menyampaikan kepada mereka dengan perkataan yang ma `rūf. Hal ini, sangatlah tepat karena perkataan yang ma ‘ū f memang tidak bisa diformulasikan secara pasti, yang justru hanya akan membatasi kata tersebut. Sebab, suatu perkataan dianggap ma ‘rūf oleh satu daerah, boleh jadi, tidak ma ‘ūf bagi daerah lain. Begitu juga, dalam kasus-kasus lain, seperti meminang wanita yang sudah habis masa 'iddahnya, menasehati istri, memberi pengertian kepada anak yatim menyangkut pengelolaan hartanya, dan lain-lain.

Salah satu bentuk perkataan ma 'rūf dicontohkan oleh al-Qurțubî, misalnya dalam konteks pembagian warisan, "Sebenarnya saya sangat ingin membagi harta warisan ini kepada kalian, namun Allah telah menentukan demikian ini", "Sebenarnya saya ingin memberi kalian lebih banyak dari ini". Namun, kata-kata yang terkesan basabasi ini akan benar-benar tidak ada gunanya sama sekali, jika ahli waris tidak memberi sedikit dari haknya. ${ }^{27}$

Dalam beberapa konteks, al-Rāzī menjelaskan, bahwa qaul ma ‘rūf adalah perkataan yang baik, yang menancap ke dalam jiwa, sehingga yang diajak bicara tidak merasa dianggap bodoh (safih); ${ }^{28}$ perkataan yang mengandung penyesalan ketika tidak bisa memberi atau membantu; 29 Perkataan yang tidak menyakitkan dan yang sudah dikenal sebagai perkataan yang baik. ${ }^{30}$

\section{e. Qaul Layyin}

Di dalam al-Qur'an hanya ditemukan sekali saja, surah Taha/20: 43-44:

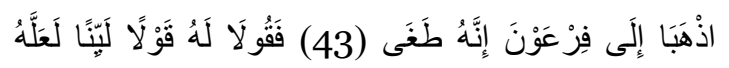

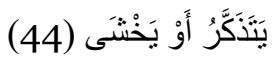

Pergilah kamu bedua kepada Fir'aun, sesungguhnya dia benar-benar telah melampaui batas; maka berbicaralah kamu berdua kepadanya (Fir'aun) dengan kata-kata yang lemah lembut, mudah-mudahan dia sadar atau takut. (Q.s. Taha/20: 43-44)

Ayat ini memaparkan kisah nabi Musa dan Harun ketika diperintahkan untuk menghadapi Fir'aun, yaitu agar keduanya berkata kepada Fir'aun dengan perkataan yang layyin. Asal makna layyin adalah lembut atau gemulai, yang pada mulanya digunakan untuk menunjuk gerakan tubuh. Kemudian kata ini dipinjam (isti`ārah) untuk menunjukkan perkataan yang lembut. ${ }^{31}$

Sementara yang dikehendaki dari qaul layyin adalah perkataan yang mengandung anjuran, ajakan, pemberian contoh, di mana si pembicara berusaha 
meyakinkan kepada pihak lain bahwa apa yang disampaikan adalah benar dan rasional, dengan tidak bermaksud merendahkan pendapat atau pandangan orang yang diajak bicara tersebut. Dengan demikian, qaul layyin adalah salah satu metode dakwah, karena tujuan utama dakwah sendiri adalah mengajak orang lain kepada kebenaran, bukan untuk memaksa atau unjuk kekuatan. ${ }^{32}$ Hanya saja, yang harus dipahami dari term layyin dalam konteks perkataan adalah bahwa perkataan tersebut bukan berarti kehilangan ketegasan; akan tetapi, perkataan yang disampaikan dengan penuh keyakinan yang akan menggetarkan jiwa orang-orang sombong yang berada di sekeliling penguasa tiran. 33

\section{f. Qaul Sadīd}

Di dalam Al-Qur'an qaul sadid disebutkan dua kali, surah an-Nisa': 9 dan al-ahzab: 70.

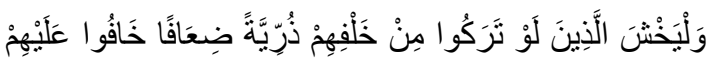

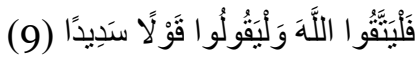

Dan hendaklah takut (kepada Allah) orang-orang yang sekiranya mereka meninggalkan keturunan yang lemah di belakang mereka yang mereka khawatir atas (kesejahteraan)nya. Oleh sebab itu, hendaklah mereka bertaqwa kepada Allah, dan hendaklah mereka berbicara dengan tutur kata yang benar. (Q.s. an-Nisā'/4: 9)

Dalam sebuah riwayat yang shahih disebutkan, bahwa ayat ini turun terkait dengan Sa'ad bin Abi Waqqash yang bermaksud mewasiyatkan seluruh kekayaannya kepada orang lain, padahal anak-anaknya masih membutuhkan harta tersebut. Rasulullah pun melarangnya. Ia hanya diizinkan untuk berwasiyat $1 / 3$ saja. Dalam hal ini, perkataan yang disampaikan haruslah tepat dan argumentatif. Inilah makna qaul sadìd.

Firman Allah yang lain:

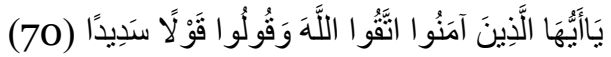

Hai orang-orang yang beriman, bertakwalah kamu kepada Allah dan katakanlah perkataan yang benar. (Q.s. al-Aḥzāb/33: 70).

Setelah Allah melarang umat muslim agar tidak menyakiti Rasulullah, maka ayat ini Allah menyeru kepada mereka untuk senantiasa dalam ketakwaan disertai dengan berkata yang benar (sadìd). Sebab nahi munkar akan memberi manfaat apabila disertai dengan pujian-pujian, sementara takwa adalah terhimpunnya segala bentuk kebaikan, dan ucapan yang benar akan melahirkan keutamaan-keutamaan. ${ }^{34}$

Secara umum qaul sadìd, ditafsirkan oleh para ulama, antara lain, perkataan yang jujur dan tepat sasaran. 35 perkataan yang lembut dan mengandung pemuliaan bagi pihak lain, ${ }_{36}$ pembicaraan yang tepat sasaran dan logis, 37 perkataan yang tidak menyakitkan pihak lain, 38 perkataan yang memiliki kesesuaian antara yang diucapkan dengan apa yang ada di dalam hatinya. 39

Bahkan, dengan berpijak pada ayat yang kedua, bahwa konsekwensi keimanan salah satunya adalah berkata dengan tutur kata yang sadìd. Atau dengan istilah lain, qaul sadīd merupakan buah penting dari tingkat 
kualitas keimanan dan ketaqwaan seseorang.

\section{Etika dalam Komunikasi Massa}

Kata "komunikasi massa" secara sederhana dapat dipahami sebagai bentuk penyampaian berita/informasi yang berimplikasi luas. Atau, komunikasi yang ditujukan kepada sejumlah khalayak yang tersebar, heterogen, dan anonim melalui media cetak atau elektronik sehingga pesan yang sama dapat diterima secara serentak dan sesaat. ${ }^{40}$ Karena itu, komunikasi massa bisa juga diidentikkan dengan penyiaran. Ada juga yang berpendapat bahwa "komunikasi massa" tidak selalu menggunakan media massa, tetapi bisa melalui pidato di hadapan orang banyak di sebuah lapangan. Yang penting menunjukkan prilaku massa (mass behavior). ${ }^{41}$ Namun, dalam artikel ini hanya dibatasi pada etika penyebaran berita dalam pandangan Islam.

Sebuah berita yang beredar di tengah masyarakat akan membentuk opini publik, namun bila tidak mengindahkan kode etik berita itu justru akan menimbulkan keresahan dan sikap saling curiga. Maka, memperhatikan kode-kode etik adalah sesuatu yang sangat urgen, apalagi jika hal itu ditegakkan di atas al-Qur`an dan alSunnah.

Para pakar komunikasi massa menyatakan, paling tidak, ada empat etika yang bisa dijadikan sebagai garis pedoman etika berkomunikasi, yaitu fairness (kejujuran), accurasy (keakuratan informasi), bebas dan bertanggungjawab, dan kritikkonstruktif. 42

\section{a. Fairness (Kejujuran)}

Sikap jujur memang diperlukan dalam banyak hal, terlebih dalam pemberitaan yang memiliki dampak cukup luas di masyarakat. Misalnya dalam kasus yang pernah terjadi pada Rasulullah; dimana ketidakjujuran salah seorang kurir beliau hampir saja berakibat perang besar antara beliau dengan Bani Mustaliq. Sebagaimana disebutkan dalam sebuah riwayat yang cukup panjang. Meski hadisnya garīb tetapi status hadisnya sahih. Riwayat ini banyak dijadikan oleh para mufassir sebagai yang melatarbelakangi turunnya surah alHujurāt/49: 6.



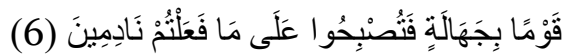
Hai orang-orang yang beriman, jika datang kepadamu orang fasik membawa suatu berita, maka periksalah dengan teliti agar kamu tidak menimpakan suatu musibah kepada suatu kaum tanpa mengetahui keadaannya yang menyebabkan kamu menyesal atas perbuatanmu itu. (Q.s. alHujurāt/49: 6)

Dari riwayat di atas dapat dilihat bagaimana kesalahpahaman hampir saja terjadi antara Rasulullah dan Bani Muțaliq, karena berita bohong yang dibawa oleh al-Walīd bin 'Uqbah bin Abi Mu'îț. Dalam hal ini, al-Walid, sebagai komunikator (penyampai berita) tidak memenuhi etika berkomunikasi dalam mengemban tugasnya, yaitu kejujuran (fairness), sehingga hampir saja Nabi 
dan para sahabat, sebagai komunikan (penerima berita). terpancing emosinya.

Di sisi lain, hadis tersebut juga memberikan pelajaran, bukan saja komunikatornya yang dituntut berlaku jujur (fairness), ${ }^{43}$ tetapi si komunikan juga harus melakukan konfirmasi terlebih dahulu, jangan percaya begitu saja terhadap informasi yang diterima sebelum mengecek kebenarannya. Apa jadinya, jika Rasulullah mempercayai begitu saja berita yang dibawa oleh alWalîd, bisa dipastikan, beliau akan menghukum Hâris dan kaumnya yang dianggap enggan membayar zakat, dan tentu saja akan menimbulkan penyesalan setelahnya.

Dalam kaitan ini, Al-Qur`an memakai kata fatabayyanū. Kata perintah tersebut mengharuskan si komunikan untuk hati-hati dan teliti dalam mencari keterangan dan penjelasan atas informasi yang diterima. Al-Ṭabarî menyatakan bahwa kata tabayyun berarti seseorang harus ekstra hati-hati dalam menyaring informasi dan mengecek kebenaran informasi yang diterima, dan jangan menerimanya mentah-mentah. 44

\section{b. Accuracy (Keakuratan Informasi)}

Hadits di atas juga mengajarkan bahwa di samping fairness (kejujuran), juga dituntut keakuratan dalam penyampaiannya (accuracy). Artinya, Seorang komunikator harus benar-benar yakin bahwa apa yang disampaikan adalah tepat, karena kesalahan informasi dalam komunikasi massa (penyiaran) akan menimbulkan kerugian yang sangat besar bagi masyarakat (penerima informasi), juga tentunya harus melihat masyarakat komunikannya, apakah informasi tersebut telah memenuhi fungsinya atau justru terjadi disfungsi.

Dalam kaitan ini, Islam sangat mengecam para penyebar berita bohong yang berbau fitnah, atau berita-berita keji, karena semua itu dapat menghancurkan sendi-sendi kehidupan masyarakat. Firman Allah:

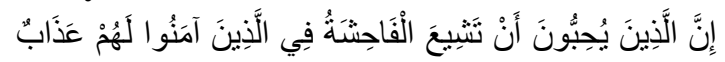

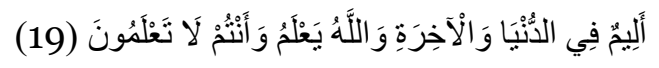

Sesungguhnya orang-orang yang suka menyebarkan berita keji di tengah-tengah orang yang beriman, bagi mereka siksa yang pedih di dunia dan akhirat... (Q.s. an-Nūr/24: 19)

Kata "siksa pedih di dunia" merujuk kepada adanya keharusan sanksi hukuman yang berat dengan undang-undang di dunia, menunjukkan bahwa penyebaran berita bohong harus dianggap sebagai salah satu bentuk tindak pidana. Atau dengan kata lain, ia bukanlah delik aduan. Bahkan, Islam memberi jaminan kepada siapa saja yang menutupi aib orang lain, akan ditutup aibnya di akhirat kelak, seperti dalam hadis:

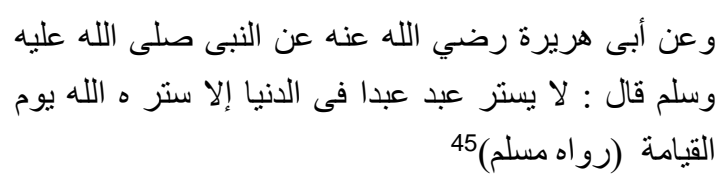

Dari Abi Hurairah r.a. dari Nabi saw. bersabda, "Tidaklah seseorang (hamba Allah) menutup aib orang lain, kecuali (aibnya) akan ditutup oleh Allah pada hari kiyamat kelak.” (HR. Muslim) 
Oleh karena itu, Allah akan memaafkan kesalahan hamba-Nya, jika dilakukan tanpa kesengajaan dan tidak dibeberkan kepada orang lain, sebagaimana dalam sebuah hadis:

و عن أبى هريرة رضي الله عنه يقول سمعت رسول الله صلى الله عليه وسلم يقول كل أمتي معافى إلا المجاهرين

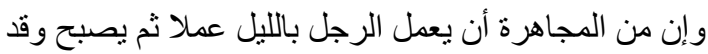

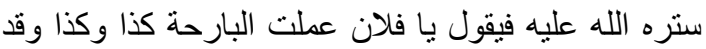
بات يستره ربه ويصبح يكثف ستر الله عنه (متفق عليه)

Dari Abu Hurairah R.A. berkata: Aku mendengar Rasulullah saw bersabda: "Setiap umatku akan dimaafkan (dosanya) kecuali al-mujahirun 47 . Termasuk kategori mujaharah adalah ketika seseorang melakukan suatu perbuatan maksiyat kemudian pada esok harinya, yang sebenarnya aibnya itu telah ditutup oleh Allah, ternyata ia bercerita kepada (orang lain): "Hai fulan, aku telah melakukan begini dan begitu semalam". Pada malam harinya Tuhannya telah menutupinya tetapi pada pagi harinya ia sendirilah yang menyingkap tutup tersebut. (riwayat. alBukhārī dan Muslim)

Menurut al-Ṭayyibī bahwa setiap dosa orang Muslim akan dimaafkan jika tidak diketahui orang lain, kecuali ia sendiri yang membeberkan rahasia (aibnya). Maka, hukumnya seperti orang yang melakukan perbuatan dosa secara terang-terangan. Bahkan, menurut alNawawī, orang semacam itu boleh diberitakan atau menjadi buah mulut, meski terbatas pada apa yang ia beberkan sendiri. Ibn al-Baț̣̄āl menyatakan bahwa orang yang melakukan perbuatan dosa secara terang-terangan atau orang yang membeberkan sendiri rahasia (aibnya), berarti ia telah menyepelekan hak-hak Allah dan Rasul-Nya, dan oleh karenanya, akan melahirkan murka Tuhan. 48

Hadis tersebut, dalam konteks penyiaran/komuniaksi massa, dapat dipahami bahwa seharusnya si komunikator harus memperhatikan rahasia seseorang (obyek berita), antara yang patut dan yang tidak patut untuk disiarkan atau disebarkan, bukan justru mancari-cari kesalahan atau berusaha keras menguak rahasia (aib) dari obyek berita tersebut dengan berbagai macam cara, yang justru si pelakunya sendiri tidak membeberkannya. Cara semacam ini tentu saja mengabaikan prinsipprinsip kepatutan dan kewajaran 49 dalam praktek penyiaran atau komunikasi massa. Bahkan, jika merujuk kepada surah an-Nūr/24: 19, ini harus dianggap sebagai tindak pidana.

\section{c. Bebas dan Bertanggungjawab}

Kebebasan pers di sini tidak harus dipahami bahwa seseorang boleh menyampaikan apa saja berita atau informasi yang ia temukan di lapangan dengan seenaknya tanpa mempertimbangkan dampak negatifnya, baik bagi individu maupun masyarakat, meskipun diperkuat oleh data-data yang akurat.

Dalam dunia pers dikenal prinsip check and recheck, yakni meneliti ulang data dan informasi, jika perlu berkalikali; dan dikenal juga cross checking (cek 
silang). Prinsip ini tentu saja harus dilakukan oleh pencari berita untuk menjaga akurasi berita, akan tetapi bukan dalam hal-hal yang berkaitan dengan rahasia aib seseorang, karena dalam Islam terdapat batas-batas tertentu --sebagaimana penjelasan di atas-- yang harus dipenuhi sebagai salah satu dari sikap fairness.

Oleh karena itu, seseorang tidak dianggap berdusta seandainya tidak mengungkapkan semua yang ia ketahui, sebagaimana dalam sebuah hadis:

عن أم كلثوم بنت عقبة أخبرته أنها سمعت رسول الله

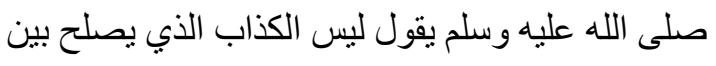
الناس فينمي خير ا أو يقول خير ا (متفق عليه)

Dari Ummi Kultsum binti 'Uqbah memberitakan kepadanya bahwasanya dia mendengar dari Rasulullah SAW. beliau bersabda: "Tidaklah dikatakan al-każżāb (pendusta) yaitu orang yang bermaksud mendamaikan di antara manusia, maka ia hanya memunculkan yang baik, atau mengatakan yang baik (H.r. al-Bukhārī dan Muslim)

Yang dimaksud dengan kata namā yanmī, yaitu menyampaikan berita demi perdamaian dan kebaikan. Karena itu, seseorang tidak dipandang berdusta jika hanya menyampaikan berita baik, sedangkan berita buruknya tidak disampaikan (sakata). Bahkan, seseorang diperbolehkan berbohong demi mendamaikan dua pihak yang bersengketa. Jadi, berbohong tidak selalu identik dengan munafik, meskipun salah satu tanda munafik adalah berbohong, karena berbohong demi kemaslahatan adalah diperbolehkan.

Hadis tersebut bukan berarti menyuruh si komunikator untuk berbohong atau tidak obyektif. Namun, yang dituntut adalah ia tidak harus menyiarkan setiap peristiwa, meskipun benar, jika hal itu justru akan menumbuhkan permusuhan di antara massa komunikan, misalnya bernuansa SARA, mengancam keselamatan orang lain, lembaga, terlebih lagi jika menyangkut keselamatan bangsa dan negara. Inilah antara lain yang dimaksud dengan kebebasan pers; yakni kebebasan yang bertanggungjawab, bukan saja menyangkut keakurasian data tetapi juga dampaknya di masyarakat.

Seandainya harus disiarkan, seyogyanya dilakukan dengan penuh kehati-hatian agar tidak ada pihak yang tersinggung oleh pemberitaan tersebut atau dikhawatirkan timbul diskomunikasi. Karena boleh jadi di antara komunikan, terdapat sekelompok orang yang tidak memiliki kejernihan hati, yang selalu memanfaatkan keadaan, yang biasa dikenal dengan memancing ikan di air keruh (provokator). Dalam kaitan ini, Al-Qur`an memberi peringatan:

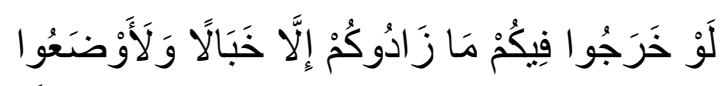

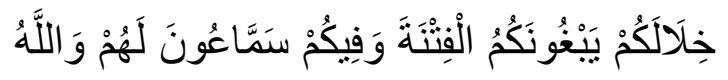

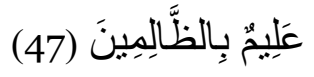
Jika mereka berangkat bersama-sama kamu, niscaya mereka tidak menambah kamu selain dari kerusakan belaka, dan tentu mereka akan bergegas maju ke muka di celah-celah barisanmu, untuk mengadakan kekacauan di antara kamu; sedang di antara kamu ada orang-orang yang amat suka mendengarkan perkataan mereka. dan 
Allah mengetahui orang-orang yang zalim.(Q.s. at-Taubah/9: 47)

Ayat tersebut mengungkap salah satu sikap orang munafik, yaitu suka memprovokasi dan mencari kesempatan untuk memperoleh informasi, yang selanjutnya disebarluaskan untuk memecah belah umat.

Redaksi وفيكم سماعون لهم menurut oleh Ibn 'Asyūr mengandung dua pengertian, ${ }^{\circ}$ pertama, bahwa di tengah kaum muslimin kemungkinan ada orangorang yang begitu saja mudah percaya terhadap setiap informasi yang mereka terima, tanpa hardus mengonfrimasi terlebih dahulu. Di sini, Al-Qur'an memperingatkan agar senantiasa hatihati dan waspada terhadap kemungkinan munculnya pemberitaan-pemberitaan yang tidak benar, yang secara sengaja dihembuskan oleh orang-orang yang berjiwa munafik; atau biasa disebut dengan "orang-orang yang tidak bertanggungjawab". Kedua, bahwa di tengah-tengah kaum muslimin memang ada orang-orang munafik yang sengaja "dipasang” untuk memata-matai, atau memutarbalikkan fakta.

\section{d. Adil dan Tidak Memihak}

Seorang komunikator semestinya hanya memihak kepada kebenaran dan tidak boleh memihak siapa pun. Namun begitu, bagi yang terkena langsung dari pemberitaan tersebut seharusnya diberi hak jawab untuk menjelaskan atau mengklirifikasi berita tersebut. Inilah yang dimaksudkan dengan prinsip keadilan. Sebagaimana yang pernah menimpa salah satu istri Rasulullah, 'Aisyah, yang dituduh telah berzina.
Peristiwa ini dikenal dengan hadīs al-ifk (berita bohong)..$^{1}$

Kasus semacam ini akan mudah sekali tersebar terutama dilakukan oleh mereka yang memang tidak suka, di sini akan muncul like and dislike. Oleh karena itu, dari kasus tersebut bisa diambil pelajaran bahwa pihak penerima berita seharusnya tidak begitu saja mempercayai berita yang tersebar, terlebih hal itu menyangkut harkat dan martabat seseorang yang dikenal luas sebagai sosok terhormat.

Dalam konteks kasus di atas, alQur`an memang memberikan klarifikasinya atas kesucian 'Aisyah, namun, secara implisit dapat dipahami bahwa seseorang yang tersangkut dalam sebuah pemberitaan harus diberi hak jawab secukupnya. Inilah yang dalam kode etik jurnalistik disebut dengan berlaku adil atau tidak memihak, dan dalam fungsinya disebut dengan perdebatan dan diskusi. Bahwa untuk mendapat penyelesaian perbedaan pendapat mengenai masalah publik, dilakukan tukar-menukar fakta serta menyediakan bukti-bukti yang relevan demi kepentingan umum. ${ }^{2}$

\section{e. Kritik-Konstruktif}

Muncul kritikan dari setiap kebijakan atau keputusan publik merupakan sebuah kewajaran. Apalagi kritikan tersebut benar-benar ditujukan kepada seorang pemimpin yang zalim, yang tidak berpihak kepada rakyat. Justru sikap semacam ini dikategorikan sebagai bentuk "jihad yang agung", sebagaimana dinyatakan dalam sebuah hadis: 
عن أبي سعبد الخدري أن النبي صلى الله عليه وسلم قال إن من أعظد الجهاد كلمة عدل عند سلطان جائر (رو اه الترمذى)

Dari Abi Sa'id al-Khudri, bahwasanya Rasulullah SAW. bersabda: "Sesungguhnya jihad yang paling agung adalah perkataan yang benar terhadap Pemimpin yang dzalim (H.r. al-Turmużī)

Kata 'adl menyangkut segala sesuatu yang mengarah kepada al-amr bi al-ma'ruf wa nahy 'an al-munkar, baik berupa ucapan maupun tulisan. AlKhaț̣ââi berkata: "Perkataan atau tulisan yang benar dianggap sebagai bentuk jihad yang paling utama, karena hal itu mengandung resiko yang cukup berat. Sebab, jika si Penguasa merasa tesinggung, maka akan membawa dampak buruk bagi si pelaku". Al-Muzhir berkata: "Biasanya penguasa zalim itu meliputi seluruh kebijakan politiknya, oleh karenanya jika ia mampu merobahnya melalui ucapan atau tulisan maka akan membawa manfaat bagi orang banyak." 54

Dalam konteks penyiaran, hadis tersebut menyuruh seorang komunikator, agar bersikap obyektif, tidak memihak, dan tidak menutuptutupi informasi kebenaran yang seharusnya diketahui oleh masyarakat. Hadis tersebut juga memberikan apresiasi kepada siapa saja yang berani memberi nasehat kepada pemimpin yang zalim. Dalam hal ini yang dituntut adalah keberanian yang bertanggung jawab, dan bukan yang bernuansa sensasional.
Namun, yang perlu diperhatikan adalah bahwa hal itu harus dikomunikasikan dengan cara-cara yang baik, dengan bahasa yang tepat, tidak menyinggung perasaan, mudah dicerna, dan dengan bahasa yang santun, karena seorang komunikator yang berhasil bukan hanya ia mampu menyampaikan informasi, tetapi sekaligus ia berhasil menjaga hubungan sosial di antara para komunikan (bermetakomunikasi).55

\section{Upaya Membangun Masyarakat Beradab}

Unsur yang terpenting di dalam komunikasi adalah komunikator, komunike, dan komunikan. Namun, ada hal lain, di luar dari ketiga unsur ini, yaitu teknik atau cara. Bahkan, dalam beberapa kasus, seringkali cara lebih penting dari pada isi, sebagaimana dalam ungkapan Arab:

$$
\text { الطريقة اهم من المادة.56 }
$$

"Cara lebih penting daripada isi"

Tentu saja, pernyataan ini masih bisa diperdebatkan. Namun, yang perlu ditegaskan di sini adalah bahwa cara penyampaian (berkomunikasi) terkadang, atau bahkan, seringkali lebih penting dari isi. Dalam hal ini, bisa digambarkan melalui sebuah kasus. Ada seorang anak muda yang baru belajar agama. Di antara materi yang pernah didengar atau diterima adalah bahwa "setiap muslim harus berani berkata benar meskipun pahit". 57 Setelah mendengar nasehat ini, yang tergambar pertama kali di benaknya adalah orang tuanya yang seringkali meninggalkan shalat atau bahkan tidak pernah shalat. 
Lalu si anak muda tersebut, dengan maksud menasehati orang tuanya, menemui orang tuanya seraya berkata, "Pak...apa bapak ngak takut masuk neraka, kok sampai setua ini bapak gak pernah shalat...". Pernyataan ini benar, tetapi cara yang disampaikan cenderung meremehkan pihak lain, terlebih ia adalah orang tuanya sendiri atau orang yang usianya jauh lebih tua. Belum lagi, jika hal itu disampaikannya dengan intonasi yang meninggi. Ini adalah contoh sederhana dari komunikasi yang tidak beradab. 58

Dengan demikian, komunikasi beradab, pada prinsipnya, merupakan suatu proses untuk mengkomunikasi kebenaran dan membangun hubungan sosial dengan komunikannya atau bermetakomunikasi. Sebab, miskomunikasi hanya akan menjadikan berpalingnya komunikan, yang berarti hilang pula informasi kebenanan itu. Inilah yang bisa dipahami dari firman Allah:

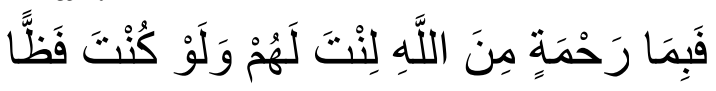

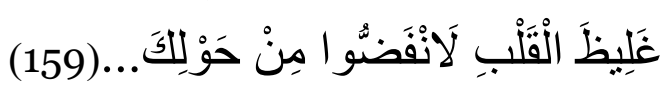

Maka disebabkan rahmat Allah kamu berlaku lemah lembut terhadap mereka. Sekiranya kamu bersikap keras lagi berhati kasar, tentulah mereka menjauhkan diri dari sekelilingmu...(Q.s. Ali 'Imran/3: 159).

Ayat ini secara khusus ditujukan kepada Rasulullah saw., namun, secara umum, ia dimaksud untuk mendidik umatnya, bagaimana cara menyikapi kebenaran kepada orang yang menolaknya, sebagai upaya untuk membangun sebuah komunikasi yang baik, yaitu dengan bersikap lembut dan santun, serta bertutur kata yang baik. 59

Secara

umum,

upaya

pembangunan komunikasi beradab bisa diklasifikasikan sebagai berikut:

\section{Komunikasi dan Pendidikan}

Pendidikan secara definitif dan tujuan telah banyak diformulasikan oleh para pakar pendidikan. Akan tetapi, dalam konteks kumunikasi beradab, pendidikan dalam hal ini lebih ditekankan kepada pendidikan berbasis karakter atau akhlaq. Sebuah pembangunan karakter (caracter building) tidak identik dengan transfer ilmu. Dalam hal ini, Islam memperkenalkan istilah tarbiyah yang berasal dari rabbā yurabbī tarbiyatan yang didefinisikan oleh al-Ișfahani, yaitu mendorong dan mengawal pihak lain menuju kepada kesempurnaannya.

Jika hal ini yang dimaksudkan dalam proses pendidikan, maka pendidikan bukanlah bersifat indoktrinasi atau propaganda, akan tetapi, suatu proses yang bersifat komunikatif. Dalam hal ini, bisa digunakan prinsip-prinsip qaul maisūr, yaitu segala bentuk perkataan yang baik, lembut, dan melegakan; menjawab dengan cara yang sangat baik, benar dan tidak mengada-ada; mengucapkan dengan cara yang wajar dan sudah dikenal sebagai perkataan yang baik bagi masyarakat setempat. Misalnya, bisa dilihat dalam kasus Luqman al-Hakim ketika menasehati anaknya. Dengan sapaan ya bunayya. ${ }^{60}$

Hanya saja, komunikasi pendidikan ini, tentu saja, sangat 
tergantung dengan usia anak tersebut. Metode komunikasi pendidikan untuk anak-anak tentunya berbeda dengan metode komunikasi untuk dewasa. Meski secara prinsip tetap sama, yaitu melahirkan generasi yang berkaraker. Misalnya, pada saat sudah dewasa, maka yang perlu diterapkan adalah prinsipprinsip qaul sadīd, yang di antaranya adalah tepat sasaran dan logis, memiliki kesesuaian antara apa yang ada di dalam hati dengan yang diucapkan.

Di sinilah proses komunikasi pendidikan tidak hanya dipahami sebagai sarana untuk transfer pengetahuan yang bersifat satu arah; akan tetapi, harus ada upaya yang sungguh-sungguh dari pihak pendidik/guru, sebagai komunikator, untuk memberikan keteladan yang baik, sebagai upaya bermetakomunikasi. Tentunya, juga kedua orang tuanya sebagai pendidik pertama dan utama bagi anak-anaknya.

Bahkan, secara naluriah, seorang anak sangat senang dan bangga jika bisa meneladani kedua orang tuanya. Ketidakpedulian orang tua, dalam proses komunikasi pendidikan ini, misalnya dengan hanya menyerahkan kepada peran guru di sekolah atau guru-guru privat yang didatangkan; atau hanya mengajarkan pelajaran-pelajaran yang berbasis kompetensi tetapi tidak menanamkan nilai-nilai berbasis karakter atau akhlaq, hanya akan melahirkan generasi-generasi yang tidak baik. Bahkan, hal ini bisa dianggap sebagai bentuk kriminalitas pendidikan. Faktor kegagalan guru/orang tua dalam proses pendidikan, antara lain, disebabkan kegagalan membangun komunikasi yang beradab tersebut.

\section{Komunikasi dan Masyarakat}

Masyarakat adalah orang kebanyakan, yang secara sosial dan pendidikan biasanya redah dan lemah, dan karenanya, masyarakat merupakan suatu kelompok manusia yang paling mudah untuk dipengaruhi dan diprovokasi. Maka, dalam konteks membangun hubungan masyarakat ini, seharusnya menerapkan prinsip-prinsip qaul balīg, yaitu bahasanya tepat, sesuai dengan yang dikehendaki, dan isi perkataan adalah suatu kebenaran, bukan semata-mata bersifat provokatif, akan tetapi yang terpenting adalah bersifat manipulatif. Di sinilah, keluhuran akhlak si komunikator menjadi sangat penting, dalam konteks membangun hubungan sosial maupun politik. Sebab, pengetahuannya tentang khlayak tidak dimaksudkan untuk menipu dan memprovokasi, namun, untuk memahami, bernegosiasi, serta bersama-sama saling memuliakan kemanusiaannya.

Tidak bisa dibayangkan, bagaimana seandainya jiwa dan karakter sang komunikator itu tidak baik, misalnya ambisius, serakah, dan lainlain, maka kemampuan retorika dan logikanya justru akan dijadikan sebagai alat untuk mempengaruhi bahkan mencuci otak masyarakatnya demi melanggengkan pengaruh dan kekuasaanya. Dalam hal ini, bisa dilihat pada kasus Fir'aun: 


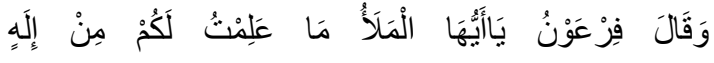

غَيْرِي...

"Dan Fir'aun berkata, "Hai pembesar kaumku, aku tidak mengetaui tuhan bagimu selain aku..." (QS. alQașaș/28: 38)

Melalui kata-katanya, Fir'aun ingin mempengarui pikiran dan jiwa masyarakat, bahwa ia memang layak diposisikan sebagai tuhan, karena kenyataannya hanya dialah yang bisa menjamin tingkat kelayakan hidup rakyat Mesir saat itu. Fir'aun paham betul dengan apa yang diinginkan oleh rakyat Mesir, yaitu hidup sejahtera, layak, terpenuhinya seluruh kebutuhan hidupnya. Ia berusaha untuk memperoleh dukungan seluas-luasnya, bukan sekedar untuk memantapkan posisinya sebagai penguasa tanpa tanding, tetapi utuk menjatuhkan lawan politiknya, yakni Musa. ${ }^{61}$

\section{Komunikasi dan Dakwah}

Inti dakwah adalah mengajak orang lain untuk mengikuti apa yang diserukannya. Oleh karenanya, kemampuan berkomunikasi dan bermetakomunikasi dengan baik menduduki posisi yang cukup strategis. Demikian itu, karena Islam memandang bahwa setiap muslim adalah da'i. Sebagai da'i, ia senantiasa dituntut agar mau dan mampu mengkomunikasikan ajaranajaran Ilahi secara baik. Sebab, kesalahan dalam mengkomunikasikan ajaran Islam, justru akan membawa akibat yang cukup serius dalam perkembangan dakwah Islam itu sendiri.

Dalam firman Allah dinyatakan:

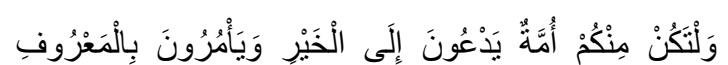

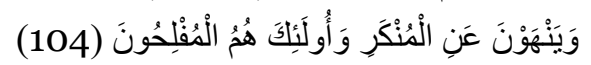
Hendaklah ada di antara kamu, suatu umat yang selalu mengajak kepada kebaikan, menyeru kepada yang ma'ruf dan mencegah dari yang munkar (Q.s. Ali 'Imran/3: 104)

Ayat tersebut memberi arahan kepada setiap anggota masyarakat, terutama umat muslim, agar selalu mengajak kepada kebaikan (la-khair), memerintahkan dengan ma'ruf, dan mencegah dari yang munkar. Tentu saja, bukan tanpa sengaja jika ayat ini mendahulukan, da'wah ilā al-khair dari pada al-amr bil-ma'ruf. Kata al-khair dipandang lebih umum dari pada alma'ruf, meskipun dari sisi penerjemahan keduanya bisa saja memiliki arti yang sama, yaitu 'kebaikan'. Oleh para ahli, kata al-khair dipahami sebagai kebaikan yang bersifat universal, seperti keadilan, kejujuran, kepedulian sosial, dan lainlain. ${ }^{2}$ Dengan demikian, mengajak kepada al-khair, sebenarnya juga menjadi concern bagi agama-agama di luar Islam. Sebab, setiap agama selalu menghendaki terciptanya kehidupan yang harmonis, aman, tentram, saling menghormati sesama, dan sebagainya. Oleh karena itu, sebagai bagian dari masyarakat, mereka harus memiliki komitmen yang sama untuk peduli terhadap segala bentuk prilaku-prilaku anti sosial yang terjadi di masyarakatnya. Dalam hal ini, umat muslim harus senantiasa tampil yang terdepan untuk menyeru atau mengkomunikasikan, sekaligus memberi keteladanan.

Dengan demikian, tegaknya nilainilai hubungan sosial yang luhur adalah 
sebagai kelanjutan dari tegaknya nilainilai keadaban itu. Artinya, masingmasing pribadi atau kelompok, dalam suatu lingkungan interaksi sosial yang lebih luas, memiliki kesediaan memandang yang lain dengan penghargaan, betapapun perbedaan yang ada, tanpa saling memaksakan kehendak, pendapat, atau pandangan sendiri. Masyarakat semacam ini pernah dibangun oleh Rasulullah saw., dan ini merupakan bukti konkrit dari keberhasilan dakwah beliau. Keberhasilan ini tentu saja tidak bisa begitu saja dipandang dari sisi kebenaran Islam dan keagungan al-Qur'an semata. Namun, ada faktor lain yang dianggap cukup dominan dalam konteks keberhasilan beliau membangunan masyarakat Madinah, yaitu kemampuan beliau dalam mengkomunikasikan ajaran-ajaran Ilahi tersebut dengan baik dan persuasif, yang ditopang oleh keluhuran budi pekerti beliau sendiri. Jika ditelusuri sirah Nabi, maka akan dijumpai betapa beliau telah menerapkan seluruh prinsip-prinsip komunikasi dalam al-Qur'an secara konsisten.

\section{Penutup}

Komunikasi tidak identik dengan menyampaikan informasi. Sebab, hal penting yang harus diperhatikan dalam proses komunikasi, adalah mengatur hubungan sosial di antara komunikan (bermetakomunikasi), baik bersifat komunikasi antar persona (interpersonal communication) maupun komunikasi massa (mass communication).

\section{Catata kaki}

${ }^{1}$ Lihat, antara lain, at-Jabari, Jāmi I-Bayān, (alMaktabah asy-Syāmilah), jilid 22, h. 8, Ibn Kasī̄r, Tafsīr al-Qur'ān al-'Az̄ìm, (al-Maktabah asySyāmilah), jilid 7, h. 489.

${ }^{2}$ Ibn 'Asyûr, al-Tahrīr wa al-Tanwīr, (al-Maktabah asy-Syāmilah), jilid 14, h. 275.

${ }^{3}$ Onong Uchjana Effendy, Ilmu Komunikasi: Teori dan Praktek, (Bandung: Remaja Rosdakarya, 1999), cet. ke-12, h. 9. 
${ }^{4}$ Onong, Ilmu Komunikasi, h. 10.

${ }^{5}$ Onong, Ilmu Komunikasi, h. 11.

${ }^{6}$ Lihat al-Sakhawī, al-Maqāșid al-Hasanah, (Beirut: Dar al-Hijrah, 1986), h. 319

${ }^{7}$ Onong, Ilmu Komunikasi, h. 16

${ }^{8}$ Onong, Ilmu Komunikasi, h. 17.

${ }^{9}$ Onong, Ilmu Komunikasi, h. 22.

${ }^{10}$ Jalaluddin Rahmat, Psikologi Komunikasi, (Bandung: Remaja Rosdakarya, 1996), cet. ke10, h. Kata Pengantar.

${ }^{11}$ James G. Robbins dan Barbara S. Jones, Komuniasi Yang Efektif, terjemahan Turman Sirait, (Jakarta: CV. Pedoman Ilmu Jaya, 1986), h. 3.

${ }^{12}$ At-Thabarī, Jāmi' al-Bayān, jilid 5, h. 153.

${ }^{13}$ Ibn 'Asyūr, al-Tahrīr, jilid 4, h. 978.

${ }^{14}$ Al-Ișfahānī, al-Mufradāt fí Garīb al-Qur'ān, (Beirut: Dar al-ma'rifah, tt.), ditahqiq oleh Muhammad Sayyid Kailani,, dalam term balagha, h. 60.

${ }^{15}$ Quraisy Shihab, Tafsir al-Mishbah, (Jakarta: Penerbit Lentera Hati, 2000), jilid 2, h. 468.

${ }^{16}$ Lihat lebih jauh Ahmad Husnul Hakim, Kaidahkaidah Penafsiran: Pedoman bagi Para Pengkaji al-Qur'an, (Depok: Penerbit eLSiQ, 2017), h. 912.

${ }^{17} \mathrm{Al}$-Ișfahānī, al-Mufradāt, pada term karama, h. 428.

${ }^{18} \mathrm{Al}-$ Ișfahānī, al-Mufradāt, h. 429.

${ }^{19}$ Sayyid Quțb, Fì Zilāl al-Qur'ān, juz 13, h. 318.

${ }^{20}$ Ibn 'Asyūr, at-Tahrīr, juz 15, h. 70.

${ }^{21}$ Ar-Rāzī, at-Tafsìr al-Kabìr, juz 9, h. 190.

${ }^{22}$ Al-Qurțubī, Al-Jāmi' li ahkām Al-Qur'ān, (alMaktabah asy-Syamilah), jilid 10, h. 107

${ }^{23}$ Al-Qurțubī, al-Jāmi', jilid 10, h. 107.

${ }^{24}$ Ar-Rāzī, Mafātīḥ al-Gaīb, jilid 20, h. 155.

${ }^{25}$ Ibn 'Asyūr, at-Tahrīr, jilid 4, h. 252 dan alSya'rawi, Tafsīr al-Sya'râwî, jilid 4: 2016

${ }^{26} \mathrm{Al}$-Ișfahānī, al-Mufradāt, pada term 'arafa, h. 331.

${ }^{27}$ Al-Qurțubī, al-Jāmi', jilid 3: h. 1630.

${ }^{28} \mathrm{Al}-\mathrm{Rāzī}$, Mafātīh, jilid 9, h. 152.

${ }^{29}$ Al-Rāzī, Mafātīh, jilid 9, h. 161.

${ }^{30}$ Al-Rāzī, Mafātīḥ, jilid 25, h. 180.

${ }^{31} \mathrm{lbn}$ 'Asyūr, al-Tahrīr, jilid 16, h. 225

${ }^{32}$ Ibn 'Asyūr, al-Taḥrīr, jilid 16, h. 225

${ }^{33}$ Sayyid Quțb, Fi Zilāl, jilid 13, h. 474.

${ }^{34}$ Ibn 'Asyūr, at-Taḥrīr, jilid 14, h. 3402.

${ }^{35}$ Al-Rāzī, Mafātīh, juz 9, h. 199.

${ }^{36}$ Al-Rāzī, Mafātīh, juz 9, h. 199. (mengutip dari al-Zamakhsyari)

${ }^{37}$ Rasyīd Riḍā, al-Manār, jilid 4, h. 327.

${ }^{38}$ Al-Sya'rāwī, Tafsir al-Sya'rāwī, jilid 4, h. 2021.
${ }^{39}$ Ibn 'Asyūr, at-Tahrīr, jilid 14, h. 3403.

${ }^{40}$ Jalaluddin Rahmat, Psikologi Komunikasi, (Bandung: Remaja Rosdakarya, 1996), cet. ke10, hal. 189.

${ }^{41}$ Onong, Ilmu Komunikasi, h. 22.

${ }^{42}$ Mafri Amir, Etika Komunikasi Massa dalam Pandangan Islam, (Jakarta: Logos Wacana IImu, 1999), hal. 55-56.

${ }^{43}$ yaitu menyangkut unsur obyektifitas, tidak memutarbalikkan fakta, berlaku adil dan tidak memihak kemana-mana kecuali kebenaran yang dtemui di lapangan.

${ }^{44}$ Al-Ṭabarî, Jāmi' al-Bayân, jilid 3, hal. 123.

${ }^{45}$ Imam Muslim, Shahih Muslim, dalam kitab alBirr wa al-Shilah wa al-Adab, bab Bisyarah Man satara Allah 'aibahu fi al-Dunya, nomor 4691.

${ }^{46}$ Imam Bukhari, Shahih al-Bukhari, dalam kitab al-Adab, bab Sitr al-Mu'min 'ala Nafsih, nomor 5608, dan Imam Muslim, Shahih Muslim, dalam kitab al-Zuhd sahabat yang terakhir wafat alRaqaiq, bab al-Nahy 'an Hatki al-Insan Sitra Nafsih, nomor 5306.

${ }^{47}$ Yaitu orang yang melakukan perbuatan buruk secara terang-terangan.

${ }^{48}$ Lihat al-Asqalani, Fath al-Bari Syarh Shahih alBukhari, dalam bab hadis di atas.

${ }^{49}$ Dalam konteks kepatutan dan kewajaran ini terdapat perbedaan yang cukup mendasar antara Islam dan etika komunikasi. Di dalam etika komunikasi setiap berita dianggap benar dan sah jika didasarkan pada data-data yang akurat, meskipun akibat dari pemberitaan itu si obyek berita merasa dipermalukan. Sementara Islam, seperti penjelasan di atas, tidaklah demikian.

${ }^{50}$ Ibn 'Asyūr, al-Taḥrīr, jilid 6, h. 300.

${ }^{51}$ Ibn Kasiīr, Tafsìr al-Qur'ān al-'Aẓim, jilid 6, h. 19.

${ }^{52}$ Onong, Ilmu Komunikasi, h. 25.

${ }^{53}$ Al-Turmużī, Sunan al-Turmużi, dalam kitab alFitan, bab Afḍal al-Jihād, nomor 2100, lihat juga Abu Dawud, Sunan Abī Dawūd, kitab alMalahim, bab al-Amr wa al-Nahy.

${ }^{54} \mathrm{Al}-\mathrm{Mubarakfuri,} \mathrm{Tuhfah} \mathrm{al-Ahważi} \mathrm{Syarh} \mathrm{Sunan}$ al-Turmużi.

${ }^{55}$ Bisa dirujuk pada penjelasan sebelumnya tentang qaul layyin.

${ }^{56}$ Ungkapan ini cukup dikenal, namun penulis tidka berhasil melacak asal muasalnya. Namun, dari segi isi dan maksudnya adalah benar.

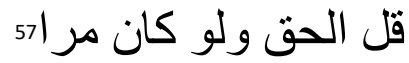

${ }^{58}$ Seharusnya ia menggunakan prinsip qaul karîm. ${ }^{59} \mathrm{Al}-S \mathrm{a}$ būnī, Mukhtașar Ibn Kasīir, jilid I, h. 331.

${ }^{60}$ Lihat Q.s. 31: 13. 
${ }^{61}$ Lihat Q.s. 51: 54.

${ }^{62}$ Lihat Ahmad Husnul Hakim, Kaidah-kaidah Penafsiran, h. 95.

\section{DAFTAR PUSTAKA}

Amir, Mafri, Etika Komunikasi Massa dalam Pandangan Islam, Jakarta:

Logos Wacana Ilmu, 1999.

Al-Ashfahani, Abu al-Qasim Abu al-Husain bin Muhammad alRaghib, al-Mufradat fi alGharib al-Qur'an, Mesir: Mushthofa al-Bab al-halabi, 1961.

Baqi, Muhammad Fuad Abd., alMu'jam al-Mufahras li alfazh alQur 'an al-Karim, Beirut: Dar al-Fikr. Cet. IV. 1994.

Al-Bukhari, Abu 'Abdillah Muhammad bin Isma'il bin Ibrahim bin al-Mughirat bin Bardizbat, Shahih al-Bukhari, Mesir: Dar al-Mathabi' al-Sya'b, (t.th.).

Effendy, Onong Uchjana, Ilmu

Komunikasi: Teori dan Praktek, (Bandung: Remaja Rosdakarya), cet XII, 1999.

Al-Fairuzzabadi, Majd al-Din Muhammad bin Ya'qub, alQamus al-Muhith, Beirut: Dar al-Fikr, 1983.

Gunadi, YS., Himpunan Istilah Komunikasi, (Jakarta: Gramedia Widiasarana Indonesia), 1998.

Al-Manzhur, Abu al-Fadhl jamal al-Din Muhammad bin Mukram ibn, Lisan al-'Arab, Beirut: Dar al-Fikr, (t. th.).
Al-Maraghi, Mushthofa, Tafsir alMaraghi, Beirut: Dar al-Fikr, (t. th.).

Muslim, Imam, Shahih Muslim, Kairo: al-Masyad al-Husaini ( $t$. th.).

Nimmo, Dan, Komunikasi Politik:

Khakayak dan Efek, penerjemah Tjun Surjaman, (Bandung: Remaja Rosdakarya), cet. II, 2000.

Sayyid Quthb, Fi Zhilal al-Qur 'an, Beirut: Dar Ihya' al-Turats al'Arabi, (t. th.).

Rahmat, Jalaluddin, Psikologi Komunikasi, (Bandung: Remaja Rosdakarya), cet. X, 1996.

-------------, Retorika Modern:

Pendekatan Praktis, Bandung:

Remaja Rosdakarya, cet. V. 2000.

Al-Razi, Fakhr al-Din, al-Tafsir alKabir, Beirut: Dar al-Fikr, (t. th.).

Al-Shabuni, Muhammad Ali, Mukhtashar Tafsir Ibn Katsir, Beirut: Dar al-Rasyad, (t. th.).

Shihab, Muhammad Quraish, Wawasan al-Qur 'an, Bandung: Mizan, cdet. II, 1996.

Membumikan alQur 'an, Bandung: Mizan, 1995.

Susanto, Astrid S., Komunikasi dalam Teori dan Praktek, (Bandung: Bina Cipta), cet. V, 1986.

Al-Suyuthi, Jalal al-Din Abd alRahman, al-Dur al-Mantsur fi Tafsir al-Ma'tsur, Beirut: dar al-Fikr, 1983.

Al-Syaukani, Muhammad bin 'Ali bin Muhammad, Fath al-Qadir, Beirut: Dar al-Fikr, (t. th.). 
Al-Syinqithi, Muhammad al-Amin, Adhwa' al-Bayan fi Idhah alQur 'an bi al-Qur'an, Beirut: Dar 'Alam al-Kutub, (t. th.).

Al-Thabari, Abu Ja'far Muhammad bin Jarir, Jami' al-Bayan fi Tafsir Ayi al-Qur 'an, (t. th.).

Thabathaba'I, Muhammad Husein, Tafsir al-Mizan, Teheran: Dar Ihya' al-Tuarts, al-'Arabi, (t. th). Umari, Akram Dhiyauddin, Masyarakat Madani: Tinjauan Historis kehidupan Zaman Nabi, (Jakarta: Gemma Insani Press), 1999.

Al-Zarkasyi, Badr al-Din Muhammad bin 'Abdillah, AlBurhan fi 'Ulum al-Qur'an, Mesir: Dar Ihya' al-Kutub al'Arabiyah, (t. th.). 